\title{
CULTURAL RESILIENCE IN KAMPUNG MAHMUD AS AN EFFORT TO PRESERVE HISTORIC AREA
}

| Received July $2^{\text {nd }}, 2018$ | Accepted July 20 2018 | Available online June $15^{\text {th }} 2019$ |

| DOI : http://dx. doi.org/10.18860/iia.v5i3.5031 |

\section{Cynthia Puspitasari}

University of Pancasila

Jakarta, Indonesia

Cynthia.puspitasari@gmail.com

\begin{abstract}
In order to achieve the concept of sustainable cities and communities, the historical and cultural richness of a city becomes one of the main sustainability modalities. The historical and cultural heritage of a city should be an important object protected by its existence and provide an identity. One of the important cultural heritages around Bandung is Kampung Mahmud. Kampung Mahmud is located 1.5 kilometres from the city of Bandung. This traditional village still holds the customs as cultural heritage and contribute to the development and spread of Islam in the city of Bandung. The existence of this village becomes an irony when its location lies between city life with all its modernity. How can the traditional kampung be able to have cultural resilience against other influences and challenges that can threaten sustainability? The study aimed to find the role of cultural resilience in Kampung Mahmud. The method used is a qualitative method that relates the instrument of cultural resilience theory to the facts that occur in the object of study. The output of this research is the principles of cultural resilience is successfully applied to Kampung Mahmud and can be an example for other regions.
\end{abstract}

\section{KEYWORDS:}

cultural, resilience, heritage, village, Kampung Mahmud

\section{INTRODUCTION}

A city can not be separated from its past. Not just giving stories, but the past or historical factor of a city can be a marker of development for the city. To achieve the concept of sustainable cities and communities, the city's historical and cultural richness is one of the main sustainability modalities. The historical and cultural heritage of a city should be an important object protected by its existence and provide a unique identity [1].

One of the important cultural heritages around Bandung is Kampung Mahmud. Kampung Mahmud located on the banks of the Citarum River, Mekar Rahayu Village, Marga Asih Subdistrict, Bandung Regency. This village is located 1.5 kilometres from the city of Bandung and until now, still, hold firm customs as intangible heritage of his ancestors. This village has a historical value of the development and spread of Islam in the city of Bandung. Tangible or physical / maintained, the Kampung Mahmud area still shows its resilience as an Islamic Sundanese village [2] [3]. This can be seen from the formation of settlement patterns and buildings that are still very traditional and included in the application of vernacular architecture. Styling house style with the dominance of wood material, bamboo cubicle walls, and the use of a non-glass material are still applied in the area [4].

The existence of this village becomes an irony when its location lies between city life with all its modernity. How can the traditional kampung be able to have cultural resilience against other influences and challenges that can threaten sustainability? Given the threats of various things can certainly lead to the extinction of cultural heritage is mainly caused by nonphysical factors such as the influence of political, economic, social and cultural developments that can affect the cultural life of the community. In addition, the area of this kampong began to be visited by many local and foreign tourists, which can also affect the pattern of life of its citizens.

The local government of Bandung Regency made a protective effort by establishing the Kampung Mahmud as a protected cultural heritage area. Of course, this determination gives a good impact when the government also participate in providing assistance in the preservation. However, efforts are needed from local communities or from other parties in pre- 
serving local wisdom from threatening factors, namely by digging resilience (resistance) on the cultural heritage.

In general, several identifiable issues relate to this research: (1) Kampung Mahmud is among the crushes of modernity from the surrounding urban life, posing challenges of political, economic, social and cultural influence that can threaten the cultural sustainability of its people; (2) Kampung Mahmud began to be visited by many tourists, so it can affect the pattern of life of its citizens. From the problems mentioned above came the formulation of the main question of the research is how cultural resilience in a cultural heritage area can be applied? From these questions, it can be clarified that this study aims to relate the cultural resilience aspects of Kampung Mahmud as an effort to preserve the cultural heritage area.

\section{URBAN HERITAGE CULTURE AND IDENTITY}

Based on Kamus Besar Bahasa Indonesia (KBBI), the definition of cultural heritage is defined as a "preserve," is a protected area to run off plants, animals, and so forth. Preservation is protection against plants, animals, and so on that are expected to become extinct. Thus, endangered animals and plants need to be scattered. The culture, according to KBBI, is the result of human reason. Of the three meanings above, cultural preservation means objects of human reason that need to be given protection, so as not to suffer damage and extinction.

Understanding cultural heritage objects according to UU No. 11 Tahun 2010 Tentang Cagar Budaya (Pasal 1 (ayat 1)) is a cultural heritage of cultural heritage, cultural heritage buildings, cultural heritage structures, and cultural heritage areas both on land and/or in water that need to be preserved because it has important value for history, science, education, religion, and/or culture through the process of determination [5].

According to UU No. 5 Tahun 1992 Tentang Benda Cagar Budaya (Pasal 1), a cultural heritage object is a man-made, mobile or immovable object in the form of a unit or group, or parts or remains, at least 50 (fifty) years old, or represents a typical style period and represents a period of style of at least 50 (fifty) years, and is considered to have an important value for history, science and culture; and natural objects that are considered to have important value for history, science, and culture [6].

Based on Perda DKI No. 9 Tahun 1999 Tentang Pelestarian dan Pemanfaatan Lingkungan dan Bangunan Cagar Budaya, the building of cultural heritage objects/ objects of buildings/environments that are protected and determined based on historical value criteria, age, originality, scarcity, landmarks, and architectural values [7]

At the UNESCO Convention on the Protection of the World Cultural and Natural Heritage (1987), the UNESCO defines the historic area as a group of buildings be it a separate or connected group, which due to its architecture, their homogeneity in its landscape, is a tremendous universal value in terms of the point of view of history, art or science [8].

Based on the criteria of UNESCO, there are tools and concepts in assessing and establishing cultural heritage areas in The Asia Pacific known as the First Principles [8]:

1) Collective mapping of cultural space, its hierarchies, symbolic language, and associations is a pre-requisite for appropriate and successful conservation.

2) Tangible cultural expressions derive their origin, value, and continuing significance from intangible cultural practices.

3) Authenticity, the defining characteristic of heritage, is a cultural-relative attribute to be found in continuity, but not necessarily in the continuity of material only.

4) The conservation process succeeds when histories are revealed, traditions revived and meanings recovered in a manuscript of knowledge.

5) Appropriate use of heritage is arrived at through a negotiation process, resulting in a life -enhancing space.

The cultural heritage area is defined as a particular area that has a cultural heritage, whether it is an object, a building or a neighbourhood, which needs to be protected and preserved from damage or extinction. Cultural heritage is determined based on the value of historical or cultural significance and the value of age, authenticity, scarcity, and value of architecture [9].

Cultural heritage contains important values related to cultural elements because it has the following values [10]:

1) Aesthetical value of the exteriors and interiors imply that the building can be an attractive object of one particular place with its beauty.

2) Spiritual value: the building may have cultural significance to a certain religious faith as in the case of a church, for instance.

3) Social value: the building may convey a sense of connection within the community and create a sense of landmark of the place.

4) Historical value: the building provides massive evidence of human civilization,

5) Symbolic value: the architectural heritage may represent the social status of the people.

6) Authentic value: original form and shape of the building's interior and exterior provide the perception of uniqueness.

These six values are what makes cultural heritage values and need to be preserved.

Due to its sustainability and preservation, the building of the cultural heritage in the visual form is more stable and long-lasting than the current verbal culture. The heritage architecture is the most important element of the cultural marker of social identity. Visual culture is stronger than conceptual in society. However, the visual heritage becomes complete with the verbal heritage [11].

The building as a mental mark interpreted heritage buildings can contribute to the personal identity of the 
inhabitants. That is a reference point on the soul that lives in the region. The value of history takes precedence over a certain aesthetic value. But the style of architecture can be a marker of the era. Heritage value means aesthetics are elements of a cultural approach to values that change from time to time [12] [13]. The process of forgetting can occur because of the economic need. There needs to be an awareness that the building of cultural heritage is a cultural mine that serves as the identity of the city and the formation of children's grandchildren.

\section{CULTURAL RESILIENCE}

Based on some literature on resilience, there are some differences in emphasis. Some scientists propose an understanding of resilience related to the internal factors of the innate individuals. Some other researchers view resilience or resilience as a process that can be passed by anyone, and not only determined by innate factors, but also other external factors.

Cultural resilience means cultural endurance. Means a self-ability or a group of people in protecting or keeping themselves from things that can threaten the continuity of the culture. Cultural resilience can be interpreted as a process of collective consciousness embodied in society to affirm, absorb, and customize various influences from other cultures through the process of learning the culture, namely enculturation, socialization, and internalization based on the same historical experience.

Cultural resilience is not meant to be static but as a dynamic one. According to Kartawinata, the principle of cultural endurance can lead, and develop the symbols that had originally existed to be re-channelled to the formation of values and forms of behaviour embodied in culture. That means cultural resilience is intended as an effort to adjust to the external situations without much damage to the culture that has become the order of life. Thus, cultural resilience, in this sense, is not intended as a cultural heritage but instead has a cultural strategy for dealing with change [14].

In the position as an agent, this culture will be adapted to emerging cultural choices, and at the same time be able to give form and identity to cultural supporters continuously, without eliminating the distinctive features of their own culture, such as language disclosure, and art, family, and kinship principles or social systems [14]. All that may be called the principles of cultural endurance. The principle of cultural resilience that includes language, religion, art, family, and kinship or also called the social system. Each of these principles of cultural resilience becomes the capital for the application of resilience to an individual or group.

\section{METHODS}

This study is an independent study which took six months to research (see Table 1). The first month is the preparation, and the second months is the observation stage. The third and fourth month is the stage of research in which there are activities of analysis and proving hypotheses and conclusions. The fifth and sixth months are the final stages of scientific writing. The place of research is carried out is related to the steps of activities carried out. At the time of preparation, analysis, and data processing, events can be done in the author's home city. However, at the time of the observation stage, the research was conducted at the location of the study object.

Table 1. Stages of The Research Activity

\begin{tabular}{|c|c|c|c|c|c|c|}
\hline \multirow[t]{2}{*}{ Stage } & \multicolumn{6}{|c|}{ Month } \\
\hline & 1 & 2 & 3 & 4 & 5 & 6 \\
\hline Preparation & & & & & & \\
\hline Observation & & & & & & \\
\hline Analysis & & & & & & \\
\hline Conclusion & & & & & & \\
\hline Writing & & & & & & \\
\hline
\end{tabular}

Based on the method of presentation, according to McMillan and Schumacher (2001), this form of research will use qualitative methods. Qualitative research undertakes a study on the perspective of participants with strategies that are interactive and flexible [15]. Qualitative research aims to understand social phenomena from participants. Departing from two things, the definition of qualitative research is a research used to examine the condition of natural objects in which the researcher is key instruments [16].

In order to observe the cultural resilience in Kampung Mahmud, key instruments are needed to analyze, assess, and discuss. The key instruments adopted from several aspects according to Community resilience, cultural identity and heritage in Nympheo, Greece and the HISTCAPE, project by Kostas Karamarkos, Rand Eppich, Alexandra Kulmer and Juan Carlos Espada. In October 1994, together with the residents, they developed a formal Strategic Plan for the continued restoration and enhancement of Nympheo. The main objectives are the sustainable development and resilience of their community and culture. The priorities in the plan included [17]:

1) Conservation and respect for the natural surroundings - forests and wildlife.

2) Protection and enhancement of their architectural and archaeological heritage.

3) Recognition and promotion of the community's traditions, customs, and history.

4) Connection to surrounding communities and region.

5) Reliable and responsible public advocacy and information dissemination.

Those five points above then implemented as key instruments for the cultural resilience assessment in this research. 


\section{DISCUSSION}

THE BACKGROUND AND HISTORY OF KAMPUNG MAHMUD

Kampung Mahmud is one of the traditional kampungs in Bandung Regency. Administratively, Kampung Mahmud belongs to the village of Mekar Rahayu, Marga Asih Subdistrict, Bandung Regency. The population of Kampung Mahmud is approximately 200 heads of households, occupying an area of \pm 4 hectares. More than half of the land is used for settlements, characteristic of traditional houses still held by some residents.

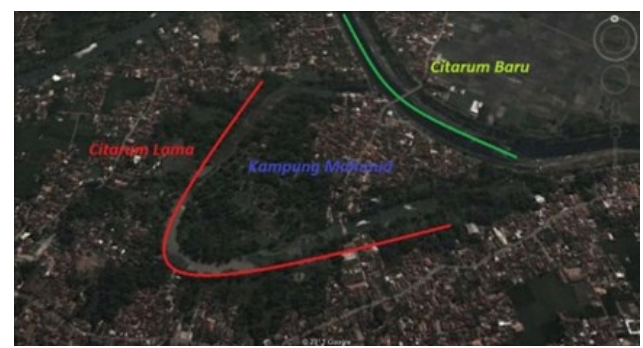

Figure 1. Aerial Map of Kampung Mahmud [18]

The village was built in the 15 th century $A D$ by Eyang Abdul Manaf who is a descendant of Cirebon guardian, Sharif Hidayatullah (Sunan Gunung Jati). At that time Eyang Abdul Manaf went to Mecca to leave his hometown and stay there for a long time. One day, Eyang Abdul Manaf wanted to return to his village. From Mecca, he brought a fistful of land which he then spread in the swamp areas of the Citarum River rivers that would later become the village of Mahmud. This location was chosen because of its remote and somewhat hidden location. It is said that such a location is very suitable as a center of struggle in spreading Islam.

One other source, H. Deden Abdullah Natapraja, said that the origin of the name of Kampung Mahmud is from the word mahmudah or akhlakul mahmudah which means good morality. This is due to the attitude and behaviour of the village community that is praiseworthy because they are honest, diligent worshipers, and amanah [19].

The obedience of Kampung Mahmud community in religion is also reflected in the desire of those who want to fulfil the fifth pillar of Islam, namely Hajj to the Holy Land. Sometimes they sacrifice their existing possessions by selling them to fulfill their existing intentions. The pattern of religious life in the community of Kampung Mahmud is also reflected in the habit that developed into a tradition or custom.

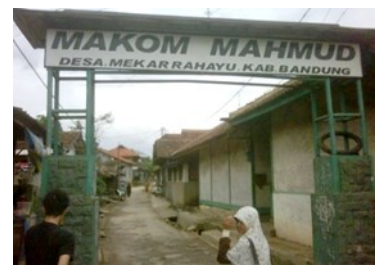

Figure 2. The Neighbourhood of Kampung Mahmud [20]
The uniqueness of the indigenous peoples of the Mahmud village, initially associated with some beliefs or values that its people are not allowed to make wells, build bridal mansions, buildings should not build will glass, use barges tiles, keep goats and swans, and should not make a drum called "bedug." Thus, the formation of buildings that stand on the site is generally made of natural materials such as wood, bamboo, natural stone, and materials that do not characterize contemporary architecture.

The shape of the existing house plan in the Kampung Mahmud area is rectangular or called with suhunan panjang. It aims to accommodate a large number of family members. When viewed from the breadth, the house building in Kampung Mahmud average is huge, from the smallest measuring $4 \times 8$ meters to size $10 \times 20$ meters, coupled with a huge yard.

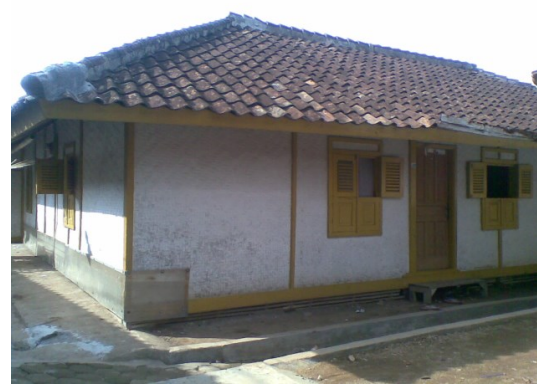

Figure 3. One of the Existing House of Kampung Mahmud [20]

The habit of building a large house is a tradition of Kampung Mahmud community. So to get a small house, there is not easy. Large and spacious homes allow the circulation of the inhabitants to move. Air circulation is also very good, where the windows are installed along the wall with a proportional size. In addition, the lighting of the house was quite good, because with the location of long-lined windows provide more light space. The outside courtyard is limited only by bamboo that is plugged into the ground. Thus, the territorial boundary between the one-yard space and the other is less clear. 'Panyaweran' can be used as a boundary of the home yard with one another. Penyaweran in Sundanese means the place where the water falls from the roof of the house or the lower part of the tile. The boundary of such a house, occurs in a group of houses near Kokolot (elders), whereas for the houses outside this group it is confined with a garden fence.

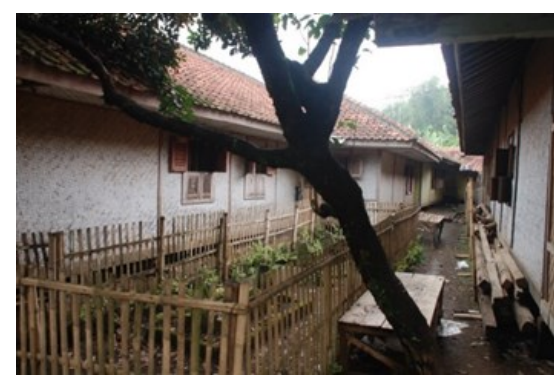

Figure 4. The Boundary Between Houses of Kampung Mahmud [20] 
In terms of architecture, one of the uniqueness that can be found is the Bumi Adat, or a traditional Sundanese stage house, which is full of philosophy of simple and religious life. Stage house is made with the main material wood and cubicle as a wall of the house. Stage house making avoids the use of glass materials, barong tiles, and walls. According to village elders, the house is a temporary abode that is not eternal. A man should build the foundation with faith and loyalty towards Allah SWT. It is according to the teachings of Islam is not good; a man is more concerned with the physical construction of a worldly nature such as housing construction. Better to do more activities outside the home with work, worship at the mosque, or stay in touch with the neighbours.

"With a house on stilts, which reflects simplicity, envy and pompous jealousy will not appear in society. The important thing is to worship, build a foundation of faith and piety that should be done with sincerity, "said H. Syafeii, whose house is still in the form of a stage since its inception.

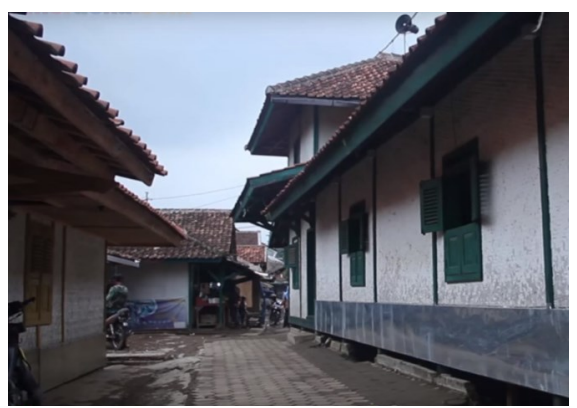

Figure 5. Bumi Adat of Kampung Mahmud [21]

As time passes, there is a tendency for these values to fade. This is due to the progress of the era, the influence of the village location close to the modern city of Bandung, and the impact of the development of the village as a pilgrimage tourist area. Nowadays, the current life of Kampung Mahmud community is quite open with the circumstances outside where they live, because of the large number of outsiders who come to the village of Mahmud to pilgrimage to the tomb of Mahmud. The openness of the indigenous people of Mahmud village to the outside world and the rapid development of the age along with the advancement of technology has brought great influence to the social and economic life of the Mahmud customary community.

This has an impact on the threat of traditional values that began to fade; this is marked by the start of the establishment of one by one building that is semipermanent. The Government of Bandung Regency then set this area as a protected cultural site of its existence. The government's efforts have a positive impact on the presence of the village, which must be maintained by the traditional values that characterize it.

Judging from social and social conditions, many people still want to keep these values as part of their lives. They do not forget how to live according to what their ancestors taught. The indigenous people of Mahmud village still have many elements, patterns, and systems of society and Sundanese culture. Their way of life has the principle of simplicity and independence and open to the outside world adapted to their customs.

The pattern of the socio-cultural life of indigenous peoples Kampung Mahmud is derived from several cultural resilience principles consisting of: (1) Sundanese art and culture, (2) Islamic religion and (3) customs (Sundanese, familial and social system). These three forms are the values of local wisdom that become the capital of resilience in facing the threat of sustainability.

\section{CULTURAL RESILIENCE IN KAMPUNG MAHMUD}

Cultural Resilience in Kampung Mahmud becomes important factors to be explored related to the existence of cultural heritage at that location. Before observing what factors can promote resilience, it is necessary to understand in advance what objects exist in the area that needs to be protected and what are the important values in it.

Assessment of important objects as cultural heritage in Kampung Mahmud, conducted based on the criteria of UNESCO [8], with the following rules:

1) Collective mapping of cultural space, its hierarchies, symbolic language, and associations is a pre-requisite for appropriate and successful conservation. In Kampung Mahmud, the teachings of Islam and Sundanese culture became the main factor underlying the formation of cultural spaces. Cultural spaces that are formed is caused by the habit or tradition of pilgrimage ancestral graves on the village.

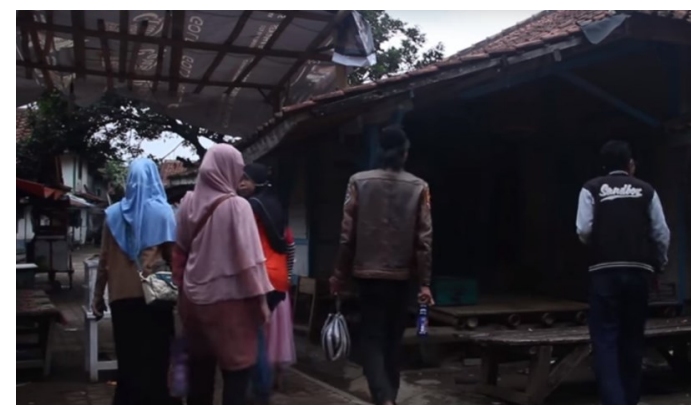

Figure 7. Cultural Space Formed by The Tradition of The Pilgrimage Ancestral Graves [21]

2) Tangible cultural expressions derive their origin, value, and continuing significance from intangible cultural practices. The cultural heritage in physical or visible form is visible in buildings and environments that still characterize traditional Sundanese or Parahyangan architecture. The semi-paved buildings, the main wooden columns, the walls of the bamboo cubicles and the roofs of the tiles are still very well preserved in homes and other public buildings. 


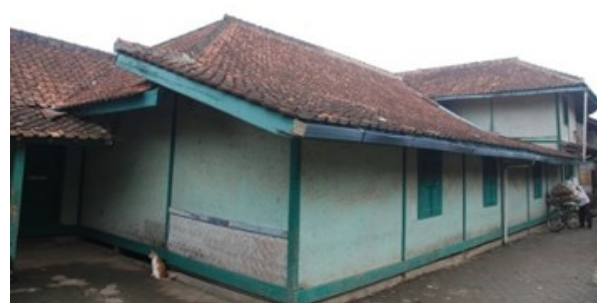

Figure 8. The Buildings as a Tangible Heritage [20]

The settlement environment with the concept of the open village, the small roads without borders and the pattern of the alleyway characterize the identity of the Sundanese village pattern.

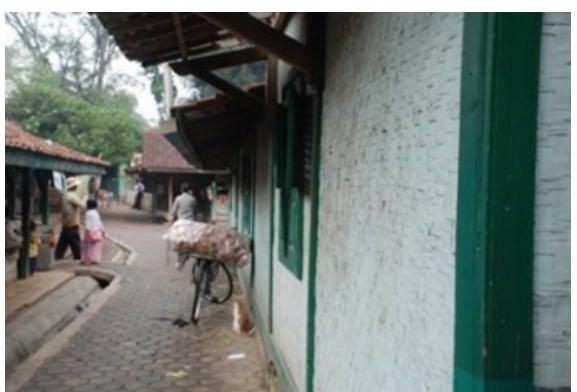

Figure 9. The Concept of Open Village as a Tangible Heritage [20]

3) Authenticity, the defining characteristic of heritage, is a cultural-relative attribute to be found in continuity, but not necessarily in the continuity of material only. The characteristic of the existing cultural heritage of the village of Mahmud is the resilience of its citizens to the simplicity based on the religious beliefs of Islam as exemplified by the great prophet of Islam, Muhammad SAW. According to Quran AlFurqan verse 67, it says: "And those who, when they spend, are not excessive, nor stingy, and are (the purchases) in the midst of such." This can be seen in building the color of the village is prohibited from making a house or other building with a luxurious impression made of brick (gedong), the building should not build with glass and using tiles barong.

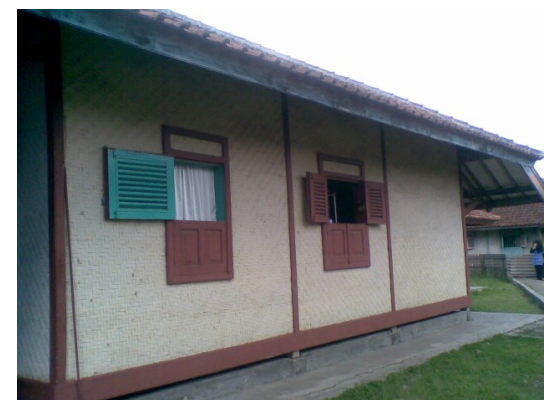

Figure 10. Simplicity Concept for The Building [20]
4)

The conservation process succeeds when histories are revealed, traditions revived and meanings recovered in a palimpsest of knowledge. Kampung Mahmud has a wealth of cultures that become distinctive identities that do not exist elsewhere. Not only intangible heritage formation is a commodity, but the history of the establishment of the village in the past as the beginning of the development of Islam in the city of Bandung is what makes the village unique. Evidence of that history which then continues to be maintained and become a tradition of pilgrimage graves are still held until today.

5) Appropriate use of heritage is arrived at through a negotiation process, resulting in a life -enhancing space. The use of cultural preservation in Kampung Mahmud is not separated from the participation of the community and the role of local government. Traditional customs and objects that are preserved today are due to the wisdom of the people to work with the government and the strong desire that comes from themselves to preserve the cultural values. The openness of the community to the pilgrimage tourism activities is also the capital of cultural preservation that must be maintained.

In assessing the elements that exist in a Cultural heritage [10], there are cultural values that need to be analyzed. In Kampung Mahmud, these cultural values include:

1) Aesthetical value: the values of Sunda traditional buildings and environments that exist in Kampung Mahmud, which aesthetically appealing and become objects that can encourage many people to appreciate and preserve its form.

2) Spiritual value: the existence of Masjid Agung Kampung Mahmud as the center of daily activities is a testament to the strong spiritual values that Mahmud Kampong. Citizens do not only use this great mosque at the time of Friday prayers but also every five times of prayer, in which male citizens are given to keep their prayers for the congregation in the mosque.

3) Social value: the building may convey a sense of connection within a community and create a sense of landmark of the place. The existence of ancestral graves founder of Kampung Mahmud and spreading the teachings of Islam (Eyang Abdul Manaf) which became the center of pilgrimage tourism activities of the tomb, a testament to the strong social values owned by Kampung Mahmud.

4) Historical value: the history of Kampung Mahmud as the beginning of the spread of Islam in Bandung, making this region has a strong historical value and should be sustainably maintained.

5) Symbolic value: The simplicity of Kampung 
Mahmud community in living everyday life can be seen from the buildings of houses and other buildings characterized by traditional architecture. The type of material that is also simple, and by the rules of the village gives typical symbolic values.

6) Authentic value: architectural formations visible from buildings and neighbourhoods in Kampung Mahmud characterize the typical Sundanese traditional village and become the identity of the region. Originality in this region in the modern era and the region surrounded by the rapid development of this technology makes this area unique and different.

For Mahmud Village to survive the challenges that can threaten the existence and sustainability of the future, cultural resilience needs to be explored so that this cultural heritage can be preserved. The excavation of cultural resilience factors [17] as the preservation capital of Kampung Mahmud, is conducted through an assessment by utilizing the following key aspects.

1) Conservation and respect for the natural surroundings - forests and wildlife. The location of Kampung Mahmud, which is close to the Citarum River, can be a disaster threat for the region. However, the beliefs of Islamic teachings held by local people make their citizens highly appreciate nature and the environment. From QS. Al-Anbiya: 107, Allah said: "we did not send you, but to be a mercy for so much nature." This becomes a strong reason from how the residents of Kampung Mahmud maintain cleanliness, manage the border area or the border with the river. The resilience of religion owned by its citizens is capital in preserving the environment.

2) Protection and enhancement of their architectural and archaeological heritage. The willingness of Kampung Mahmud community in maintaining and preserving the cultural heritage owned is a very important aspect of resilience. This awareness is derived from their obedience to the religious leaders in the village. When the leaders advise-keeping the values of simplicity they have to adhere, the majority of citizens will follow the advice. This is what makes the cultural heritage in Kampung Mahmud maintained, although there is a small part that experienced changes due to technological challenges.

3) Recognition and promotion of the community's traditions, customs, and history. The history and culture of Kampung Mahmud community as a grave pilgrimage destination has now become quite popular news. Many migrants from other cities come to visit the region to enjoy the Islamic activities and the grave pilgrims that exist in the area. It can also be a capital for resilience in the region when cultural or non-physical preservation products are preserved and valued. Not only history, but Sundanese language became the ancestral language, Sundanese customs and Islamic teachings that are still executed until today is a strong capital of culture in the face of external challenges and influences.

4) Connection to surrounding communities and region. The openness of Kampung Mahmud community to the preservation of culture and its utilization can have a positive impact so that the village is often visited by cultural, educational, Islamic, and government communities. Citizen participation in providing guidance to visitors resulted in an increased number of visitors to the region. This encourages the creation of cultural resilience in Kampung Mahmud.

5) Reliable and responsible public advocacy and information dissemination. Bandung Regency Government along with the cultural and the educational community, periodically give counselling to the citizens of Kampung Mahmud regarding the status of this kampong as a kampung adat. This is then followed by concrete steps in the form of assistance in the implementation of tourism activities, in order to prevent exposure of outside influences unstoppable that can threaten the customs of local communities. In addition, assistance is also carried out in the maintenance of buildings and the environment. Physical development in such a way should refer to local rules that follow the "simplicity" suggestion in the form of vernacular and traditional architecture.

\section{CONCLUSION}

Kampung Mahmud is in the challenge to the crush of modernity from the city life around it, posing challenges of political, economic, social, and cultural influence that could threaten the cultural survival of its people. However, with the principles of cultural resilience in the form of Sundanese, Sundanese customs, the teachings of Islam and the social system that holds the values of culture and religion, external threats can be faced with strong resilience.

The traditional Kampung Mahmud began to be visited by many tourists so that it can affect the pattern of life of its citizens. This can certainly be a threat if social and economic conditions in it are not ready for the change. The influence of tourism can have a major impact on the susceptibility of cultural heritage. Therefore, a strategy is needed to strengthen the cultural resilience aspects in Kampung Mahmud so that the heritage of the cultural heritage, both tangible and intangible heritage, can be maintained. 


\section{REFERENCES}

[1] M. García-Hernández, M. de la Calle-Vaquero, and C. Yubero, "Cultural Heritage and Urban Tourism: Historic City Centres under Pressure," Sustainability, vol. 9, no. 8, p. 1346, Aug. 2017.

[2] W. D. Pratiwi, I. Susanti, and Samsirina, "The Impact of Religious Tourism on a Village of Peri-urban Bandung: Transformation in Placemaking," in Proceedings of the 6th International Conference of Arte-Polis, Singapore: Springer Singapore, 2017, pp. 61-72.

[3] N. Nurdiani and W. Katarina, "The study of buildings and neighborhood of Mahmud cultural village," IOP Conf. Ser. Earth Environ. Sci., vol. 195, no. 1, 2018.

[4] M. Gartiwa, "Climate Adaptive Technology In Maintaining Vernacularism Of Urban Kampong Case study]: KampungAdat (Indiginous ) Mahmud, Bandung District, West Java," no. Icetd, 2013.

[5] P. Indonesia, Undang-Undang Nomor 11 tahun 2010 tentang Cagar Budaya. Indonesia, 2010.

[6] P. Indonesia, Undang-Undang Nomor 5 tahun 1992 tentang Benda Cagar Budaya. Indonesia, 1992.

[7] P. DKI, Pemerintah DKI Nomor 9 tahun 1999 tentang Pelestarian dan Pemanfaatan Lingkungan dan Bangunan Cagar Budaya. Indonesia, 1999.

[8] UNESCO, Protection of the World Cultural and Natural Heritage. 1987.

[9] J. Blake, "On Defining the Cultural Heritage," Int. Comp. Law Q., vol. 49, no. 1, pp. 61-85, Jan. 2000.

[10] B. Hernowo, D. S. Agustina, and A. H. Lulu, "Heritage Facadism And Its Concept Of Value," in 2nd International Conference On Urban Heritage And Sustainable Infrastructure Development (UHSID), 2013.

[11] B. Hernowo and A. Erdoğan, "Jakarta as Freilichtmuseum of Architectural History," in
PROCEEDING, Jak_A2014: Jakarta as a City and Dream, 2014, pp. 1-13.

[12] L. Prosper, "Wherein Lies the Heritage Value? Rethinking the Heritage Value of Cultural Landscapes from an Aboriginal Perspective," George Wright Forum, vol. 24, no. 2, pp. 117124, 2007.

[13] L. H. Fredheim and M. Khalaf, "The significance of values: heritage value typologies reexamined," Int. J. Herit. Stud., vol. 22, no. 6, pp. 466-481, Jul. 2016.

[14] H. D. Ismadi, Ketahanan Budaya Pemikiran dan Wacana. Jakarta: Pusat Penelitian dan Pengembangan Kebudayaan, Insignia, 2014.

[15] J. H. McMillan and S. Schumacher, Research in Education. New York: longman, Inc, 2001.

[16] Sugiyono, Metode Penelitian Kuantitatif, Kualitatif dan R\&D. Bandung: Afabeta, 2011.

[17] K. Karamarkos, R. Eppich, A. Kulmer, and J. C. Espada, "Community Resilience, Cultural Identity and Heritage: Nympheo, Greece, and the HISTCAPE Project," Practice Insights, vol. 3 , Scotland, pp. 18-19, 2014.

[18] Z. P. Syahadah, "Kampung Mahmud dan Sisa Kearifan Lokalnya," Komunitas Aleut, 2015. [Online]. Available: https:// komunitasaleut.com/2015/09/30/kampungmahmud-dan-sisa-kearifan-lokalnya/. [Accessed: 20-May-2018].

[19] “National Geographic Indonesia," 2013.

[20] K. Bandung, "Kampung Adat Mahmud," Disparbud. Jabarprov, 2011. [Online]. Available: http://www.disparbud.jabarprov.go.id/wisata/ dest-det.php?id=25\&lang=id. [Accessed: $20-$ Apr-2018].

[21] N. Abdurohman and M. Z. Atsari, "Kampung Adat Mahmud, tanah suci umat Islam di Bandung," Merdeka.com, 2016. [Online]. Available: https://www.merdeka.com/peristiwa/ kampung-adat-mahmud-tanah-suci-umat-islam -di-bandung.html. [Accessed: 20-May-2018]. 